\title{
DEVELOPMENT OF A TECHNIQUE FOR DETERMINING CADMIUM, LEAD, ARSENIC WITH THE ETAAS METHOD IN MEDICINAL PLANT RAW MATERIALS
}

\author{
ALEXANDER NIKULIN, OLGA POTANINA *, MOHSEN ALYUSSEF, VASILIY VASIL'EV, \\ RIMMA ABRAMOVICH, OLEG NOVIKOV, NIKOLAY BOYKO, ARKADIY KHROMOV, \\ EVGENIY PLATONOV
}

Peoples' Friendship University of Russia (RUDN University), 6 Miklukho-Maklaya Street, Moscow, 117198, Russian Federation

*corresponding author: microly@mail.ru

Manuscript received: December 2020

\begin{abstract}
Electrothermal atomic absorption spectrometry (ETAAS) is one of the most well-known methods for determining trace amounts of elements in natural objects, since it is simple in instrumentation and rather cheap. It is especially promising for the pharmaceutical analysis of medicinal plant raw materials for quality control purposes. A new unified ETAAS technique for the determination of cadmium, lead and arsenic in solutions obtained after acid decomposition (with $\mathrm{HNO}_{3}$ ) of plant raw material under microwave heating conditions has been developed. It was shown that cadmium can be determined without a modifier, while for lead and arsenic the presence of a modifier is necessary. Inexpensive and widely available substances were proposed as modifiers: $1 \%$ solution of ascorbic acid (for lead), $1 \%$ solution of $\mathrm{Ni}\left(\mathrm{NO}_{3}\right)_{2}$ (for arsenic), which were previously used in the Russian Federation exclusively in geochemical studies. The conditions for the preparation of the analysed samples are proposed. The using prospects of the developed technique for the natural substances quality control, as well as its universality for the analysis of plant raw material of various morphological groups have been demonstrated. The technique was validated in terms of specificity, accuracy, precision, repeatability, linearity, range, robustness. The technique can be recommended for determination of these ecotoxicants accumulation in wild-growing and cultivated medicinal plants.
\end{abstract}

\section{Rezumat}

Spectrometria de absorbție atomică electrotermică (ETAAS) este una dintre cele mai cunoscute metode de determinare în urme a elementelor. Aceasta este deosebit de promițătoare pentru analiza farmaceutică a materiilor prime din plante medicinale. A fost dezvoltată o nouă tehnică ETAAS pentru determinarea simultană a cadmiului, plumbului și arsenului în soluții obținute după descompunerea acidă $\left(\mathrm{cu} \mathrm{HNO}_{3}\right)$ a materiei prime vegetale cu microunde. Cadmiul poate fi determinat fără adjuvanți, în timp ce pentru plumb și arsen este necesară prezența unui aditiv. Ca adjuvanți au fost propuşi: soluție de acid ascorbic $1 \%$ (pentru plumb), soluție de $\mathrm{Ni}\left(\mathrm{NO}_{3}\right)_{2} 1 \%$ (pentru arsen). S-au demonstrat perspectivele utilizării tehnicii dezvoltate pentru controlul calității produselor vegetale. Tehnica a fost validată în termeni de specificitate, acuratețe, precizie, repetabilitate, liniaritate, interval de detecție, robustețe, și poate fi recomandată pentru determinarea acumulării acestor compuși ecotoxici în plantele medicinale din flora spontană și cultivate.

Keywords: heavy metals, medicinal plants, atomic absorption spectrometry

\section{Introduction}

Currently, herbal medicines are attracting increasing interest due to the undoubted advantages over synthetic drugs: low toxicity, softness, duration, complexity of therapeutic effect [16]. The vast majority of natural origin drugs are produced from medicinal plants, which can accumulate significant amounts of elements. This is due to a change in the industrial environment and the inclusion of toxic elements in natural biogeochemical cycles, which necessitates ongoing monitoring of the ecotoxicants content $[7,13]$. For their determination in medicinal plant raw materials, various physicochemical methods of analysis are used, which are included in most pharmacopoeias of developed countries $[3,6$, 21-24], including the State Pharmacopoeia of the
Russian Federation of the XIV edition (Rus. Ph. XIV) [21]. According to Rus. Ph. XIV, to confirm the quality of medicinal plant raw materials, the determination of four elements is required: cadmium, arsenic, lead and mercury. Mercury is easily determined by the "cold vapour" method, while the routine determination of cadmium, lead and arsenic in a laboratory causes significant difficulties due to the absence in Rus. $\mathrm{Ph}$ XIV reliable techniques for the analysis of the plant raw material. A similar situation is observed in some other world pharmacopoeias (American (USP), British (BP), Japanese (JP), International pharmacopoeia (Int. $\mathrm{Ph}$.), where only the most general recommendations are given [3, 22-24]. Spectral methods, such as flame and electrothermal atomic absorption spectrometry (FAAS and ETAAS, respectively), inductively coupled 
plasma atomic emission spectrometry (ICP-AES), inductively coupled plasma mass spectrometry (ICPMS), are the most modern and reliable methods for determining the elemental composition. Acid decomposition of samples in closed systems under microwave heating is the most efficient sample preparation method [10]. Unlike USP, BP and JP, some definition conditions are given in Eur. Ph. that cannot be considered sufficiently optimal [6]. For example, for determination of elements in natural substances, the samples are decomposed using mixtures of nitric and hydrochloric acids and an additive of sulfuric acid leading to the precipitation of some analytes, for example, lead sulphate (II). Algorithms for transferring of samples into a solution under conditions of microwave heating are not fully written down - heating time, magnetron power is given (it is not necessary currently, as modern equipment automatically adjusts it, based on temperatures in Teflon vessels), and temperatures are not recorded. There are disadvantages at the stage of determination too. The arsenic content analysis is recommended to be performed in hydride consoles, which is not rational enough, since under certain conditions arsenic can be determined by the ETAAS method. The solutions of magnesium nitrate and ammonium dihydrogen phosphate are proposed as modifiers and rarely have the required purity for ETAAS. And the absence of modifiers can lead to the loss of the determined elements already at the stage of pyrolysis $\left(800^{\circ} \mathrm{C}\right.$ according to $\mathrm{Ph}$. Eur.). In Rus. Ph. XIV, the attention is paid to sample preparation in open systems leading to the loss of nanogram quantities of analytes; autoclave decomposition using hardly volatile sulfuric acid not allowing to obtain stable forms of elements cadmium, lead and arsenic. And also explosive perchloric acid, Carius tubes/Kjeldahl flasks are still widely used. These techniques and approaches are time consuming and do not allow automating the process of sample preparation, which would be very useful in factory laboratories involved in the analysis of medicinal plant raw materials, plant substances and medicinal products based on them. All these disadvantages can be overcome by using the acid decomposition of samples using nitric acid (to obtain stable, highly soluble forms of elements) placed in a microwave field [8], in combination with modern spectral analysis methods. However, the use of microwave decomposition systems in Rus. Ph. XIV has not received enough attention.

Considering the requirements of Rus. Ph. XIV for the heavy metals content in natural substances $(\mathrm{Pb}$ 6.0, Cd 1.0, $\mathrm{Hg} 0.1$ and As $0.5 \mathrm{mg} / \mathrm{kg}$ ), the following conclusion can be drawn that the ICP-AES and FAAS methods are not suitable for the determination of ultralow content of cadmium, lead and arsenic due to its low sensitivity.

The ICP-MS and ETAAS are one of the main modern methods for determining elements trace in medicinal plant raw materials $[2,4,5,9,15,26]$. Each of these methods has its own advantages and disadvantages $[1,12,14]$, which are summarized in Table I.

Comparison of ETAAS and ICP-MS methods for the determination of $\mathrm{Cd}, \mathrm{Pb}$ and $\mathrm{As}$

\begin{tabular}{|c|c|c|}
\hline \multirow{2}{*}{ Description of methods } & \multicolumn{2}{|l|}{ Method } \\
\hline & ETAAS & ICP-MS \\
\hline \multirow{3}{*}{ Achievable detection limits, $\mu \mathrm{g} / \mathrm{L}$} & 0.02 for $\mathrm{Cd}$ & $0.00 \mathrm{n} *$ for $\mathrm{Cd}$ \\
\hline & 0.2 for $\mathrm{Pb}$ & $0.000 \mathrm{n}$ for $\mathrm{Pb}$ \\
\hline & 0.8 for As & $0.000 \mathrm{n}$ for As \\
\hline Dynamic range & $1-1.5$ & $5-7$ \\
\hline Reproducibility of definition & $1-3 \%$ & $1-2 \%$ \\
\hline Multi-element measurement mode & No & Yes \\
\hline Spectral influences & Insignificantly & Significant \\
\hline Matrix influences & Significant & Significant \\
\hline Operating costs & Low & High \\
\hline $\begin{array}{l}\text { Compatibility with various } \\
\text { decomposition methods }\end{array}$ & $\begin{array}{l}\text { The ability to analyse aqueous solutions with a } \\
\text { sufficiently high content of organic substances }\end{array}$ & $\begin{array}{c}\text { Only aqueous concentrates can be } \\
\text { analysed }\end{array}$ \\
\hline
\end{tabular}

However, to realize such low detection limits in practice using ICP-MS in the vast majority of cases is not possible due to the influence of various factors (polyatomic interference and matrix effects) on the formation of the analytical signal [1], for the correction of which various approaches are used: reaction/collision cells, math modelling, desolvation systems [12]. However, the use of these methods is not a universal approach, and the matrix influences eliminating problem remains unresolved. An additional limitation of the ICP-MS method is the strict mineralization requirements of the analysed solutions, which is usually less than $0.2 \%$. ETAAS is one of the most widely used instrumental methods for determining trace amounts of elements in natural objects solution, since this atomization method provides low detection limits at the level of ng/g. The use of this highly sensitive method does not impose strict restrictions on the composition of the analysed solution, which is especially convenient when determining analytes in solutions obtained by acid decomposition of medicinal plant raw materials. 
Spectral influences in the ETAAS method are extremely rare, however, matrix influences can be significant [18]. Nevertheless, when determining cadmium, lead and arsenic in solutions obtained by acid decomposition of organic raw materials, usually there is no difficulty in determining cadmium, but in determination of lead and arsenic, these elements may be lost at the heat treatment stage due to their high volatility. To eliminate this undesirable phenomenon, as well as to increase the heat treatment temperature, which is necessary for the most complete separation of matrix atoms from analyte atoms in the process of ETAAS determination, is possible using modifiers. The most universal modifier is palladium nitrate and its mixtures with magnesium nitrate [28]. It is extremely expensive and may not always be available to laboratories involved in the analysis of natural substances. A simpler alternative in determining lead is to use a $1 \%$ ascorbic acid solution as a modifier [20], which has a reduction effect (restores the $\mathrm{Pb}^{2+}$ form to $\mathrm{Pb}^{0}$ ), and arsenic is a $1 \%$ solution of divalent nickel $[11,27]$, which has the ability to form intermetallic compounds with volatile elements.

Thus, the analysis of literature data allows to conclude, that ETAAS is one of the most popular method for determining elements in natural objects [17, 19, 25], available, the most selective in relation to analytes, less demanding alternative to the composition of the tested solutions in comparison with ICP-MS. ETAAS is presented in general monographs in Ph. Eur. and JP. However, the USP does not pay enough attention to this method and ICP-MS is recommended as the main method for determining element trace concentrations. The aim of this work is to develop a combined technique for the quantitative determination of cadmium, lead and arsenic with the ETAAS method in solutions obtained after acid decomposition of medicinal plant raw materials samples under microwave heating.

\section{Materials and Methods}

\section{Objects of analysis}

Leonurus cardiaca (Motherwort) herb, Matricaria (chamomile) flowers, Tanacetum flowers, Aerva lanata herb, Hypericum (Saint-John's-wort) herb, Thalli Laminariae, Tussilago (coltsfoot) leaves, Helichrysum arenarium (dwarf everlast) flowers, Birch leaves, Melissa officinalis (Lemon balm) herb, Orthosiphon stamineus herb, Linum seeds, Arctium (burdock) roots, Chimaphila umbellata (pipsissewa) herb, Bergenia crassifolia fermented leaves, Oak bark, Origanum (Oregano) herb, Polygonum aviculare (prostrate knotweed, birdweed) herb, Senna leaves, Centaurium herb, Sanguisorba officinalis roots and rhizomes, Elecampane (Inula) roots, Tiliae flores, Taraxacum officinale roots, Plantago major leaves, Althaea officinalis herb, Viola tricolor (heartsease) herb, Uvae Ursi (Bearberry) leaves, Vaccinium vitis-idaea (lingonberry) leaves, Orthilia herb, Bergenia crassifolia roots and rhizomes.

Apparatus and Materials

To determine cadmium, lead and arsenic, an atomic absorption spectrometer with electrothermal atomization Varian AA-240 (Australia), a Milestone Ethos 1Microwave oven (Italy), and an Atilon ATL-120d4-I analytical balance (Germany) were used.

Reagents and Solutions

High-purity concentrated nitric acid "Trace metal grade" from Fisher Chemical (Belgium), hydrogen peroxide (A.C.S. Reagent, Acros Organics, Belgium), a standard sample (SS) of cadmium, lead and arsenic ions at a concentration of $1,000 \mu \mathrm{g} / \mathrm{mL}$ from Merck (Germany), ascorbic acid Chimmed (chemically pure, Russia), nickel(II) nitrate hexahydrate Chimmed (chemically pure, Russia), purified water were used. Preparation of modifier solutions

$1 \%$ solution of ascorbic acid. $1 \mathrm{~g}$ of ascorbic acid was placed in a $100 \mathrm{~mL}$ volumetric flask and $70 \mathrm{~mL}$ of water were added, the sample was completely dissolved, the volume of the solution was diluted to the volume with the same solvent.

$1 \%$ solution of $\mathrm{Ni}\left(\mathrm{NO}_{3}\right)_{2} .1 .6 \mathrm{~g}$ of nickel (II) nitrate hexahydrate was placed in a $100 \mathrm{~mL}$ volumetric flask, $70 \mathrm{~mL}$ of water were added, the sample was completely dissolved and the volume of the solution was diluted to the volume with the same solvent.

Preparation of test solution

$0.30-0.50 \mathrm{~g}$ (exact weight) of plant-based substances were placed in Teflon vessels, $5 \mathrm{~mL}$ of concentrated nitric acid and $0.5 \mathrm{~mL}$ of hydrogen peroxide were added. The vessels were carefully sealed and placed in the microwave oven. Decomposition of samples was carried out according to the program presented in Table II.

\section{Table II}

The acid decomposition program for samples containing substances from plant origin under microwave heating

\begin{tabular}{|c|c|c|}
\hline phase & Time, min & Temperature, ${ }^{\circ} \mathrm{C}$ \\
\hline 1 & 20 & $25^{\circ} \mathrm{C} \rightarrow 170^{\circ} \mathrm{C}$ \\
\hline 2 & 20 & $170^{\circ} \mathrm{C}$ \\
\hline 3 & 50 & $170^{\circ} \mathrm{C} \rightarrow 25^{\circ} \mathrm{C}$ \\
\hline
\end{tabular}

The vessels were opened and the contents were filtered into a $100 \mathrm{~mL}$ volumetric flask through Blue Ribbon filter paper, then the volume of the solution was diluted to the volume with water.

The obtained solutions were further analysed with ETAAS method according to the procedure described below. The solutions were used freshly prepared.

Comparative solution

$5 \mathrm{~mL}$ of the concentrated nitric acid and $0.5 \mathrm{~mL}$ of the hydrogen peroxide were added to an empty Teflon vessel. The vessels were carefully sealed and placed in a microwave oven. Decomposition of samples was carried out according to the program presented in 
Table II. The vessels were opened and the contents were filtered into a $100 \mathrm{~mL}$ volumetric flask through Blue Ribbon filter paper, then the volume of the solution was diluted to the volume with water. The obtained solutions were further analysed with ETAAS method according to the procedure described below. The solution was used freshly prepared.

Preparation of standard solutions

Standard solution no. 1: $2 \mathrm{~mL}$ of the SS cadmium was placed in a $100 \mathrm{~mL}$ volumetric, $1 \mathrm{~mL}$ of the concentrated nitric acid was added, dissolved in water with stirring, the solution was diluted to the volume with the same solvent and stirred (cadmium concentration $20 \mu \mathrm{g} / \mathrm{mL}$ ). The solution was used freshly prepared.

Standard solution no. 2: $1 \mathrm{~mL}$ of the standard solution no. 1 was placed in a $100 \mathrm{~mL}$ volumetric flask, $1 \mathrm{~mL}$ of the concentrated nitric acid was added, dissolved in water with stirring, the volume of the solution was diluted to the volume with the same solvent and stirred (cadmium concentration $200 \mathrm{ng} / \mathrm{mL}$ ). The solution was used freshly prepared.

Standard solution no. 3: $500 \mu \mathrm{L}$ of the standard solution no. 2 was placed in a volumetric flask, the volume of the solution was diluted with water to $10 \mathrm{~mL}$, and stirred (cadmium concentration of $10 \mathrm{ng} / \mathrm{mL}$ ). The solution was used freshly prepared.

Standard solution no. 4: $2 \mathrm{~mL}$ of the SS lead was placed in a $100 \mathrm{~mL}$ volumetric flask, $1 \mathrm{~mL}$ of the concentrated nitric acid was added, dissolved in water with stirring, the solution was diluted to the volume with the same solvent and stirred (lead concentration $20 \mu \mathrm{g} / \mathrm{mL}$ ). The solution was used freshly prepared.

Standard solution no. 5: $2.5 \mathrm{~mL}$ of the standard solution no. 4 was placed in a $100 \mathrm{~mL}$ volumetric flask, $1 \mathrm{~mL}$ of the concentrated nitric acid was added, dissolved in water with stirring, the solution was diluted to the volume with the same solvent and stirred (lead concentration $500 \mathrm{ng} / \mathrm{mL}$ ). The solution was prepared extempore.

Standard solution no. 6: $2 \mathrm{~mL}$ of the $\mathrm{SS}$ arsenic was placed in a $100 \mathrm{~mL}$ volumetric flask, $1 \mathrm{~mL}$ of the concentrated nitric acid was added, dissolved in water with stirring, the solution was diluted to the volume with the same solvent and stirred (arsenic concentration $20 \mu \mathrm{g} / \mathrm{mL}$ ). The solution was prepared extempore.

Standard solution no. 7: $2.5 \mathrm{~mL}$ of the standard solution no 6 was placed in a $100 \mathrm{~mL}$ volumetric flask, $1 \mathrm{~mL}$ of the concentrated nitric acid was added, dissolved in water with stirring, the solution was diluted to the volume with the same solvent and stirred (arsenic concentration $500 \mathrm{ng} / \mathrm{mL}$ ). The solution was prepared extempore.

Standard solution no. 8: $1000 \mu \mathrm{L}$ of the standard solution no. 3, $400 \mu \mathrm{L}$ of the standard solution no. 5,
$800 \mu \mathrm{L}$ of the standard solution no. 7 were placed in a $10 \mathrm{~mL}$ volumetric flask, the solution was diluted to the volume and stirred (cadmium concentration $1 \mathrm{ng} / \mathrm{mL}$, lead - $20 \mathrm{ng} / \mathrm{mL}$ and arsenic - $40 \mathrm{ng} / \mathrm{mL}$ ). The solution was prepared extempore.

Standard solution no. 9: $500 \mu \mathrm{L}$ of the standard solution no. $3,200 \mu \mathrm{L}$ of the standard solution no. 5, $400 \mu \mathrm{L}$ of the standard solution no. 7 were placed in a $10 \mathrm{~mL}$ volumetric flask, the solution was diluted to the volume with water and stirred (cadmium concentration - $0.5 \mathrm{ng} / \mathrm{mL}$, lead - $10 \mathrm{ng} / \mathrm{mL}$ and arsenic - $20 \mathrm{ng} / \mathrm{mL}$ ). The solution was prepared extempore.

Standard solution no. 10: $250 \mu \mathrm{L}$ of the standard solution no. $3,100 \mu \mathrm{L}$ of the standard solution no. 5 , $200 \mu \mathrm{L}$ of the standard solution no. 7 were placed in a $10 \mathrm{~mL}$ volumetric flask, the solution was diluted to the volume with water and stirred (cadmium concentration - $0.25 \mathrm{ng} / \mathrm{mL}$, lead - $5 \mathrm{ng} / \mathrm{mL}$ and arsenic - $10 \mathrm{ng} / \mathrm{mL}$ ). The solution was prepared extempore.

Standard solution no. 11: $100 \mu \mathrm{L}$ of the standard solution no. $3,50 \mu \mathrm{L}$ of the standard solution no. 5, $100 \mu \mathrm{L}$ of the standard solution no. 7 were placed in a volumetric flask with a volume of $500 \mathrm{~mL}$, the solution was diluted to the volume with water and stirred (cadmium concentration - $0.1 \mathrm{ng} / \mathrm{mL}$, lead $2.5 \mathrm{ng} / \mathrm{mL}$ and arsenic $-5 \mathrm{ng} / \mathrm{mL}$ ). The solution was prepared extempore.

\section{Results and Discussion}

To optimize the determination technique of cadmium, lead and arsenic the following conditions were experimentally selected: (1) temperature-time conditions for the determination of cadmium, lead, arsenic with the ETAAS method and (2) acid decomposition conditions for plant-based samples during microwave decomposition.

Selecting temperature-time conditions for the determination of cadmium, lead, arsenic

For determination of cadmium, lead and arsenic using the ETAAS method, the temperature-time conditions were selected. The analytes were determined in graphite pyro-coated furnace using modifiers - a $1 \%$ solution of ascorbic acid (for lead), a $1 \%$ solution of $\mathrm{Ni}\left(\mathrm{NO}_{3}\right)_{2}$ (for arsenic) using the most intense wavelengths: cadmium - at $228.8 \mathrm{~nm}$, lead - at $283.3 \mathrm{~nm}$, arsenic at $193.7 \mathrm{~nm}$. The aliquot volume $(10-20 \mu \mathrm{L})$ of the modifier is equal to the aliquot volume of the test sample.

Preliminary construction of pyrolysis-atomization curves made it possible to propose conditions of cadmium, lead, arsenic determination. The determination of elements was carried out by the height of the analytical signal. The determination conditions of elements are presented in Table III. 
Table III

Conditions for the determination of cadmium, lead and arsenic by the ETAAS method in test solutions obtained by the decomposition of medicinal plant raw materials under conditions of Microwave heating

\begin{tabular}{|c|c|c|c|c|c|c|}
\hline \multirow{2}{*}{ Element } & \multirow{2}{*}{ Wavelength, nm } & \multirow{2}{*}{ Modifier } & \multicolumn{4}{|c|}{ Temperature and time conditions } \\
\hline & & & Stage number & $\mathbf{T}^{*},{ }^{\circ} \mathbf{C}$ & $\mathrm{t}^{* *}, \mathrm{c}$ & $\mathbf{v}^{* * * *}, \mathrm{~L} / \mathrm{min}$ \\
\hline \multirow{9}{*}{$\mathrm{Cd}$} & \multirow{9}{*}{228.8} & \multirow{9}{*}{ absent } & 1 & 85 & 5.0 & 0.3 \\
\hline & & & 2 & 95 & 40.0 & 0.3 \\
\hline & & & 3 & 120 & 10.0 & 0.3 \\
\hline & & & 4 & 350 & 5.0 & 0.3 \\
\hline & & & 5 & 350 & 1.0 & 0.3 \\
\hline & & & 6 & 350 & 2.0 & 0.0 \\
\hline & & & 7 & 1900 & 0.8 & 0.0 \\
\hline & & & 8 & 1900 & 2.0 & 0.0 \\
\hline & & & 9 & 2000 & 2.0 & 0.3 \\
\hline \multirow{9}{*}{$\mathrm{Pb}$} & \multirow{9}{*}{283.3} & \multirow{9}{*}{ Ascorbic acid solution ( $1 \%)$} & 1 & 85 & 5.0 & 0.3 \\
\hline & & & 2 & 95 & 40.0 & 0.3 \\
\hline & & & 3 & 120 & 10.0 & 0.3 \\
\hline & & & 4 & 400 & 5.0 & 0.3 \\
\hline & & & 5 & 400 & 1.0 & 0.3 \\
\hline & & & 6 & 400 & 1.0 & 0.0 \\
\hline & & & 7 & 2100 & 0.9 & 0.0 \\
\hline & & & 8 & 2100 & 2.0 & 0.0 \\
\hline & & & 9 & 2200 & 2.0 & 0.3 \\
\hline \multirow{9}{*}{ As } & \multirow{9}{*}{193.7} & \multirow{9}{*}{$\mathrm{Ni}\left(\mathrm{NO}_{3}\right)_{2}$ Solution (1\%) } & 1 & 85 & 5.0 & 0.3 \\
\hline & & & 2 & 95 & 40.0 & 0.3 \\
\hline & & & 3 & 120 & 10.0 & 0.3 \\
\hline & & & 4 & 1400 & 5.0 & 0.3 \\
\hline & & & 5 & 1400 & 1.0 & 0.3 \\
\hline & & & 6 & 1400 & 1.0 & 0.0 \\
\hline & & & 7 & 2500 & 0.6 & 0.0 \\
\hline & & & 8 & 2500 & 2.0 & 0.0 \\
\hline & & & 9 & 2600 & 2.0 & 0.3 \\
\hline
\end{tabular}

$10 \mu \mathrm{L}$ of standard solutions no. 8 - 11, blank and test solutions, as well as the modifier solutions sequentially introduced into the graphite furnace of the atomizer at least 3 times. The concentration of each element in the test solution and the comparative solution was determined from the obtained calibration curves. The content of cadmium, lead, arsenic in the raw materials of medicinal plant $(\mathrm{X}, \mathrm{ppb})$ was calculated by the formula (1):

$$
X=\frac{\left(C-C_{0}\right) \cdot V}{a},
$$

where, $C$ is the concentration of the element in the test solution, obtained from the calibration curve, $\mathrm{ng} / \mathrm{mL} ; C_{0}$ is the concentration of the element in a blank solution obtained from the calibration curve, $\mathrm{ng} / \mathrm{mL} ; V$ is volume of test/blank solution, $\mathrm{mL} ; a$ is the weight of raw materials sample, $\mathrm{g}$.

Selection of acid decomposition conditions for samples during microwave heating

The conditions for the acid decomposition for raw materials samples of medicinal plant were selected based on the arsenic as the most one from all three studied elements prone to loss during the sample preparation.

The additive technique was used to control possible losses, $5 \mathrm{~mL}$ of concentrated nitric acid, $0.5 \mathrm{~mL}$ of concentrated hydrogen peroxide were added to the plant raw material (Rose Hips) which were milled to a particle size and passed through a sieve with $1 \mathrm{~mm}$ hole size, $5 \mathrm{~mL}$ of concentrated nitric acid, $0.5 \mathrm{~mL}$ of concentrated hydrogen peroxide were added. Then an additive solution was added after transferring the solution obtained from the decomposition into a 100 $\mathrm{mL}$ volumetric flask, the concentration of arsenic was about $20 \mathrm{ng} / \mathrm{mL}$.

It was found that the most optimal temperature range was $150-170^{\circ} \mathrm{C}$, at this range not only the decomposition of the test material was achieved, but also no loss of arsenic was observed (the introduced amount -20 $\mathrm{ng} / \mathrm{mL}$, and was found $-22 \mathrm{ng} / \mathrm{mL}$ ). Obviously, cadmium and lead (which are significantly less volatile) were not lost in the process of sample preparation.

The incomplete decomposition of the medicinal plants organic matrix was observed at temperatures below $150^{\circ} \mathrm{C}$, which is confirmed by UV/VIS spectrophotometer.

A set of absorption bands was observed at $346-386$ $\mathrm{nm}$, which indicated the presence of undecomposed substances of organic origin in the test solution. The loss of the determined element was observed when the temperature raised above $170^{\circ} \mathrm{C}$. Based on the obtained data, the following conditions were 
FARMACIA, 2021, Vol. 69, 3

selected for the decomposition of medicinal plant raw materials during microwave heating: the weight of plant raw material sample is $0.3-0.5 \mathrm{~g}$, the volume of concentrated nitric acid is $5 \mathrm{~mL}$, the volume of concentrated hydrogen peroxide is $0.5 \mathrm{~mL}$, decomposition time - $20 \mathrm{~min}$; decomposition temperature $-170^{\circ} \mathrm{C}$.
The developed technique was tested to determine cadmium, lead and arsenic in medicinal plant raw materials of various morphological groups. The data are presented in Table IV.

lead and arsenic determination in plant substances, $n g / g(n=3, p=0$

\begin{tabular}{|c|c|c|c|}
\hline Sample & Cd & $\mathbf{P b}$ & As \\
\hline \multicolumn{4}{|l|}{ Herbs } \\
\hline 1. Aerva lanata herb & $25 \pm 10$ & -* $^{*}$ & - \\
\hline 2. Althaea officinalis herb & $4 \pm 2$ & - & - \\
\hline 3. Centaurium herb & - & - & - \\
\hline 4. Chimaphila umbellata (Pipsissewa) herb & $16 \pm 3$ & - & - \\
\hline 5. Hypericum (Saint-John's-wort) herb & - & $150 \pm 21$ & - \\
\hline 6. Leonurus cardiac (Motherwort) herb & $15 \pm 5$ & - & - \\
\hline 7. Melissa officinalis (Lemon balm) herb & - & $263 \pm 30$ & - \\
\hline 8. Origanum (Oregano) herb & - & - & - \\
\hline 9. Orthilia herb & $9 \pm 4$ & - & - \\
\hline 10. Orthosiphon stamineus herb & - & $95 \pm 30$ & - \\
\hline 11. Polygonum aviculare (Prostrate knotweed, Birdweed) herb & - & $90 \pm 25$ & - \\
\hline 12. Viola tricolor (Heartsease) herb & $27 \pm 11$ & - & - \\
\hline \multicolumn{4}{|l|}{ Flowers } \\
\hline 13. Helichrysum arenarium (Dwarf everlast) flowers & $15 \pm 7$ & - & - \\
\hline 14. Matricaria (Chamomile) flowers & $9 \pm 3$ & $122 \pm 12$ & - \\
\hline 15. Tanacetum flowers & $4 \pm 2$ & - & - \\
\hline 16. Tiliae flowers & $4 \pm 2$ & - & - \\
\hline \multicolumn{4}{|l|}{ Leaves } \\
\hline 17. Bergenia crassifolia fermented leaves & $10 \pm 4$ & $231 \pm 38$ & - \\
\hline 18. Birch leaves & $14 \pm 7$ & - & - \\
\hline 19. Tussilago (Coltsfoot) leaves & $14 \pm 5$ & - & - \\
\hline 20. Plantago major leaves & $4 \pm 2$ & $91 \pm 23$ & - \\
\hline 21. Senna leaves & - & $106 \pm 39$ & - \\
\hline 22. Uvae Ursi (Bearberry) leaves & $1 \pm 1$ & - & - \\
\hline 23. Vaccinium vitis-idaea (Lingonberry) leaves & - & - & - \\
\hline \multicolumn{4}{|l|}{ Roots and rhizomes } \\
\hline 24. Arctium (Burdock) roots & $8 \pm 4$ & - & - \\
\hline 25. Bergenia crassifolia roots and rhizomes & $8 \pm 3$ & $112 \pm 13$ & - \\
\hline 26. Elecampane (Inula) roots & $6 \pm 2$ & - & - \\
\hline 27. Sanguisorba officinalis roots and rhizomes & - & $128 \pm 31$ & - \\
\hline 28. Taraxacum officinale roots & $8 \pm 2$ & - & - \\
\hline \multicolumn{4}{|l|}{ Other organs } \\
\hline 29. Linum seeds & $11 \pm 4$ & - & - \\
\hline 30. Oak bark & $8 \pm 3$ & $104 \pm 20$ & - \\
\hline 31. Thalli Laminariae & $21 \pm 6$ & - & $8,481 \pm 12$ \\
\hline 32. Rose Hips & - & - & - \\
\hline Maximum value & $27 \pm 11$ & $263 \pm 30$ & $8,481 \pm 12$ \\
\hline A limit of element content in substances of plant origin according to Rus. Ph XIV & 1000 & 6000 & $500 / 90,000 * *$ \\
\hline
\end{tabular}

Taking into account the ultra-low concentration (ng/g) of the determined elements and their extremely uneven distribution in volume even in powdered natural samples, it can be confidently stated that the data in Table IV shows satisfactory efficiency of the developed technique. As can be seen from data of Table IV, maximum value of toxic elements $\left(\mathrm{X}_{\mathrm{Pb}}=263 \pm 30 \mathrm{ng} / \mathrm{g}, \mathrm{X}_{\mathrm{Cd}}=27 \pm 11\right.$ $\mathrm{ng} / \mathrm{g}$ and $\mathrm{X}_{\mathrm{As}}=8481 \pm 12 \mathrm{ng} / \mathrm{g}$ ) are not exceed the limits that required according to Rus. $\mathrm{Ph}$ XIV $\left(\mathrm{X}_{\mathrm{Pb}}=\right.$ $6000 \mathrm{ng} / \mathrm{g}, X_{\mathrm{Cd}}=1000 \mathrm{ng} / \mathrm{g}$ and $X_{\mathrm{As}}=90000 \mathrm{ng} / \mathrm{g}$ ) in all tested samples of plant raw materials.

To prove the efficiency, the following validation characteristics of the developed technique in the case of Rose Hips were evaluated: specificity, linearity, accuracy, repeatability. It is necessary to consider: (A) concentrations of detectable elements is ultra- 
FARMACIA, 2021, Vol. 69, 3

low (the level of detectable contents is ppb (ng/g)); (B) the samples are multicomponent (complex) and have a wide range of matrix components concentrations regarding to the ultra-low concentrations of elements in the natural substances, which ultimately leads to an extremely uneven distribution of trace analyte contents over the volume of the analysed sample, which cannot be overcome by quarting; (C) Points A, B make it impossible to use mathematical statistics techniques to process the results in full.

Accuracy

The accuracy of the technique for the quantitative determination of elements was proved using the additives method by adding the exact amount of the element to the test solution obtained by acid decomposition of Rose Hips samples. Three parallel determinations were carried out for each additive ( 9 measurements, 3 concentrations within the determined range).
The accuracy character was evaluated by calculating the recovery, which is the ratio between the introduced and found element content in $\mathrm{ng} / \mathrm{mL}$.

Three acid decompositions of Rose Hips from Teflon vessels were shifted to three volumetric flasks with a volume of $100 \mathrm{~mL}$ respectively; $20 \mathrm{~mL}$ of water were added and stirred. Then respectively were added: (1) 1, 2.5 and $5 \mathrm{~mL}$ of standard solution no. 3; (2) 1, 2 and $4 \mathrm{~mL}$ of standard solution no. 5; (3) 2, 4 and $8 \mathrm{~mL}$ of standard solution no. 7. The volumes were diluted to the volume with water, and mixed.

The accuracy results of the technique for the quantitative determination of elements are presented in Table $\mathrm{V}$ and are in the range $70.0-130.0 \%$ for all three additives.

Relative standard deviations (RSD) are presented in Table VI and do not exceed $7.0 \%$ for all elements at the selected wavelengths.

Table V

Accuracy determination for $\mathrm{Cd}, \mathrm{Pb}$ and $\mathrm{As}$

\begin{tabular}{|c|c|c|c|c|c|}
\hline $\begin{array}{c}\text { Wavelength, } \\
\text { nm }\end{array}$ & $\begin{array}{c}\text { Introduced, } \\
\text { ng/mL }\end{array}$ & $\begin{array}{c}\text { A, } \\
\text { relative unit }\end{array}$ & $\begin{array}{c}\text { founded, } \\
\mathrm{ng} / \mathrm{mL}\end{array}$ & $\begin{array}{c}\text { A, } \\
\text { relative unit }\end{array}$ & $\begin{array}{c}\text { Recovery, } \\
\%\end{array}$ \\
\hline \multirow{9}{*}{$228.8(\mathrm{Cd})$} & 0.10 & 0.397298 & 0.07 & 0.281245 & 70.8 \\
\hline & 0.10 & 0.399584 & 0.07 & 0.278109 & 69.6 \\
\hline & 0.10 & 0.422580 & 0.07 & 0.283591 & 67.1 \\
\hline & 0.25 & 0.934471 & 0.28 & 1.003170 & 107.4 \\
\hline & 0.25 & 0.908168 & 0.28 & 1.003090 & 110.5 \\
\hline & 0.25 & 0.929055 & 0.28 & 0.980287 & 105.5 \\
\hline & 0.50 & 1.419270 & 0.44 & 1.384000 & 97.5 \\
\hline & 0.50 & 1.396090 & 0.44 & 1.265060 & 90.6 \\
\hline & 0.50 & 1.425880 & 0.44 & 1.285190 & 90.1 \\
\hline \multirow{9}{*}{$283.3(\mathrm{~Pb})$} & 5 & 0.286390 & 4.89 & 0.284639 & 99.4 \\
\hline & 5 & 0.292915 & 4.89 & 0.296152 & 101.1 \\
\hline & 5 & 0.295396 & 4.89 & 0.287367 & 97.3 \\
\hline & 10 & 0.542646 & 9.86 & 0.550960 & 101.5 \\
\hline & 10 & 0.556134 & 9.86 & 0.556922 & 100.1 \\
\hline & 10 & 0.551992 & 9.86 & 0.552188 & 100.0 \\
\hline & 20 & 0.948204 & 15.2 & 0.778332 & 82.1 \\
\hline & 20 & 0.956935 & 15.2 & 0.773113 & 80.8 \\
\hline & 20 & 0.956428 & 15.2 & 0.786918 & 82.3 \\
\hline \multirow{9}{*}{ As (193.7) } & 10 & 0.085374 & 12.4 & 0.096412 & 112.9 \\
\hline & 10 & 0.083691 & 12.4 & 0.104536 & 124.9 \\
\hline & 10 & 0.078041 & 12.4 & 0.091354 & 117.1 \\
\hline & 20 & 0.156015 & 22.8 & 0.0179334 & 114.9 \\
\hline & 20 & 0.140099 & 22.8 & 0.0180298 & 128.7 \\
\hline & 20 & 0.149354 & 22.8 & 0.0163539 & 109.5 \\
\hline & 40 & 0.307373 & 44.5 & 0.0332867 & 108.3 \\
\hline & 40 & 0.308991 & 44.5 & 0.0342783 & 110.9 \\
\hline & 40 & 0.295475 & 44.5 & 0.0339324 & 114.8 \\
\hline \multicolumn{3}{|c|}{ Statistical Characteristics } & Cd & $\mathbf{P b}$ & As \\
\hline \multicolumn{3}{|c|}{ Lowest value, $\%$} & 67.1 & 80.8 & 108.3 \\
\hline \multicolumn{3}{|c|}{ Highest value, $\%$} & 110.5 & 101.1 & 128.7 \\
\hline \multicolumn{3}{|c|}{ Average value, $\%$} & 88.8 & 91.0 & 118.5 \\
\hline \multicolumn{3}{|c|}{ Standard deviation } & 17.1 & 9.17 & 6.90 \\
\hline \multicolumn{3}{|c|}{ The standard deviation of the average result } & 5.70 & 3.06 & 2.30 \\
\hline \multicolumn{3}{|c|}{ Coefficient of variation $(\mathrm{CV}), \%$} & 19.3 & 10.1 & 5.82 \\
\hline \multicolumn{3}{|c|}{ Confidence interval $(P=0.95)$} & 13.2 & 7.06 & 5.31 \\
\hline
\end{tabular}


Relative standard deviations RSD $(\mathrm{n}=3)$

\begin{tabular}{|c|c|c|}
\hline Element & The concentration determined by the calibration graph, $\mathbf{~ g / m L}$ & $\mathbf{R S D}, \boldsymbol{\%}$ \\
\hline \multirow{3}{*}{$\mathrm{Cd}$} & 0.07 & 0.98 \\
\cline { 2 - 3 } & 0.28 & 1.30 \\
\cline { 2 - 3 } & 0.44 & 4.90 \\
\hline \multirow{3}{*}{$\mathrm{Pb}$} & 4.89 & 2.10 \\
\cline { 2 - 3 } & 9.86 & 0.60 \\
\cline { 2 - 3 } & 15.2 & 0.90 \\
\hline \multirow{3}{*}{$\mathrm{As}$} & 12.4 & 6.80 \\
\cline { 2 - 3 } & 22.8 & 5.40 \\
\cline { 2 - 3 } & 44.5 & 1.49 \\
\hline
\end{tabular}

\section{Precision/Repeatability}

For repeatability determination, RSD was calculated by the quantitative determination of metals in the test solutions of following elements: $0.5 \mathrm{ng} / \mathrm{mL}$ for cadmium, $10 \mathrm{ng} / \mathrm{mL}$ for lead, $20 \mathrm{ng} / \mathrm{mL}$ for arsenic $(n=6)$, because the content of these metals initially was below the detection limit in the analysed objects. The results are shown in Table VII. RSD does not exceed $5 \%$.

Repeatability assessment of the technique for the quantitative determination of elements in solutions of substances with a metal concentration: $0.5 \mathrm{ng} / \mathrm{mL}$ for cadmium, $10 \mathrm{ng} / \mathrm{mL}$ for lead and $20 \mathrm{ng} / \mathrm{mL}$ for arsenic $(\mathrm{n}=6)$

\begin{tabular}{|c|c|c|c|c|c|}
\hline Element & $\begin{array}{c}\mathrm{A}, \\
\text { relative unit }\end{array}$ & $\overline{A_{\text {cp }}}$ & $\begin{array}{l}\text { Standard } \\
\text { deviation }\end{array}$ & $\begin{array}{c}\text { The coefficient of variation, } \\
\%\end{array}$ & $\begin{array}{c}\text { Confidence } \\
\text { interval }\end{array}$ \\
\hline \multirow{6}{*}{$\mathrm{Cd}$} & 1.30946 & \multirow{6}{*}{1.29441} & \multirow{6}{*}{4.85} & \multirow[t]{6}{*}{$x_{1}$} & \multirow{6}{*}{5.00} \\
\hline & 1.27504 & & & & \\
\hline & 1.38400 & & & & \\
\hline & 1.26506 & & & & \\
\hline & 1.28519 & & & & \\
\hline & 1.24769 & & & & \\
\hline \multirow{6}{*}{$\mathrm{Pb}$} & 0.550960 & \multirow{6}{*}{0.551154} & \multirow{6}{*}{0.59} & \multirow{6}{*}{1.07} & \multirow{6}{*}{0.62} \\
\hline & 0.556922 & & & & \\
\hline & 0.552188 & & & & \\
\hline & 0.558158 & & & & \\
\hline & 0.544621 & & & & \\
\hline & 0.544074 & & & & \\
\hline \multirow{6}{*}{ As } & 0.186513 & \multirow{6}{*}{0.181250} & \multirow{6}{*}{0.45} & \multirow{6}{*}{2.48} & \multirow{6}{*}{0.48} \\
\hline & 0.179334 & & & & \\
\hline & 0.180298 & & & & \\
\hline & 0.186930 & & & & \\
\hline & 0.178953 & & & & \\
\hline & 0.175474 & & & & \\
\hline
\end{tabular}

\section{Specificity}

To assess the specificity of the technique for the quantitative determination of $\mathrm{Cd}, \mathrm{Pb}$ and $\mathrm{As}$ with the ETAAS method, the absorption signals of a comparison solution were obtained, the signals of standard solutions of cadmium $(0.25 \mathrm{ng} / \mathrm{mL})$, lead $(10 \mathrm{ng} / \mathrm{mL})$ and arsenic (20 ng/mL).

Based on the obtained data, it can be concluded that the solvent does not affect the analytical signals of cadmium, lead and arsenic. The addition method (as depicted in the "Accuracy" section) showed the absence of interfering influences on the analytical signals of the determined elements.

Linearity

To determine the linearity of the technique for the quantitative determination of cadmium, lead and arsenic, a series of standard solutions $(0.1-1.0 \mathrm{ng} / \mathrm{mL}$ for cadmium, 2.5 - $20 \mathrm{ng} / \mathrm{mL}$ for lead, 5 - $40 \mathrm{ng} / \mathrm{mL}$ for arsenic) were prepared (see Preparation of standard and test solutions).

The dependence of elements analytical signal on their concentration in the solution is presented in Table VIII. As can be see the correlation coefficients in Table VIII (for the linear parts of the calibration curves) for cadmium, lead and arsenic were more than 0.995, which confirms the linearity of quantitative determination up to $0.25 \mathrm{ng} / \mathrm{mL}$ (for cadmium), $10 \mathrm{ng} / \mathrm{mL}$ (for lead) and $40 \mathrm{ng} / \mathrm{mL}$ (for arsenic) inclusively.

During the operation with the graphite furnace, linearity after 200 - 300 cycles increases to $0.5 \mathrm{ng} / \mathrm{mL}$ (for cadmium) and $20 \mathrm{ng} / \mathrm{mL}$ (for lead). 
Table VIII

Linearity determination for elements

\begin{tabular}{|c|c|c|c|c|}
\hline \multirow{2}{*}{ Wavelength, nm } & \multicolumn{5}{|c|}{ Concentration of Cadmium, ng/mL } \\
\cline { 2 - 5 } & $\mathbf{0 . 1}$ & $\mathbf{0 . 2 5}$ & $\mathbf{0 . 5}$ & $\mathbf{1 . 0}$ \\
\hline \multirow{3}{*}{228.8} & 0.397298 & 0.934471 & 1.419270 & 1.738070 \\
\cline { 2 - 5 } & 0.399584 & 0.908168 & 1.396090 & 1.705710 \\
\cline { 2 - 5 } & 0.422580 & 0.929055 & 1.425880 & 1.723590 \\
\hline $\mathrm{S}_{\mathrm{cp}} \%$ & 0.406487 & 0.923898 & 1.413740 & 1.722450 \\
\hline RSD, \% & 4.87 & 1.50 & 1.10 & 0.90 \\
\hline Correlation coefficient & \multicolumn{5}{|c|}{0.9994} \\
\hline \multirow{2}{*}{ Wavelength, nm } & 2.5 & 5 & 10 & 20 \\
\cline { 2 - 5 } & 0.137774 & 0.286309 & 0.542646 & 0.948204 \\
\cline { 2 - 5 } & 0.136783 & 0.292915 & 0.556134 & 0.956935 \\
\cline { 2 - 5 } 283.3 & 0.144038 & 0.295396 & 0.551992 & 0.956428 \\
\hline $\mathrm{S}_{\mathrm{cp}}$ & 0.139532 & 0.291540 & 0.549942 & 0.946369 \\
\hline RSD, \% & 2.80 & \multicolumn{5}{|c|}{1.0000} & 1.00 & 1.60 \\
\hline Correlation coefficient & \multicolumn{5}{|c|}{ Concentration of Arsenic, ng/mL } \\
\hline \multirow{2}{*}{ Wavelength, nm } & 5 & 10 & 20 & 40 \\
\cline { 2 - 5 } & 0.041067 & 0.085374 & 0.156015 & 0.307373 \\
\hline \multirow{3}{*}{193.7} & 0.040964 & 0.083691 & 0.140099 & 0.308991 \\
\cline { 2 - 5 } & 0.043581 & 0.078041 & 0.149354 & 0.295475 \\
\hline $\mathrm{S}_{\mathrm{cp}}$ & 0.041870 & 0.082369 & 0.148489 & 0.303946 \\
\hline RSD, \% & 3.50 & 4.70 & 5.40 & 2.40 \\
\hline Correlation coefficient & \multicolumn{5}{|c|}{1.0000} \\
\hline
\end{tabular}

The total number of heating-atomization cycles in a pyro-coated graphite furnace should not exceed 800 1000.

Range

The technique for the quantitative determination of $\mathrm{Cd}, \mathrm{Pb}$ and $\mathrm{As}$ by the ETAAS is applicable for concentration range from 0.0 to $0.3(0.5) \mathrm{ng} / \mathrm{mL}$ for $\mathrm{Cd}$, from 0.5 to 15 (20) $\mathrm{ng} / \mathrm{mL}$ for $\mathrm{Pb}$ and from 10 to $40 \mathrm{ng} / \mathrm{mL}$ for As in the test solution.

Accuracy, linearity and precision are established for interval values and values within the interval: linearity from 0.0 to $0.3(0.5) \mathrm{ng} / \mathrm{mL}$ for $\mathrm{Cd}$, from 0.0 to 10 (20) $\mathrm{ng} / \mathrm{mL}$ for $\mathrm{Pb}$ and from 0.0 to $40 \mathrm{ng} / \mathrm{mL}$ for $\mathrm{As}$ validity, repeatability.

\section{Robustness}

Standard solutions no. $8-11$ and the tested solutions are stable for 24 hours at a temperature less than $8^{\circ} \mathrm{C}$, which was confirmed by the absence of a decrease in the value of determined elements analytical signals. A $1 \%$ solution of ascorbic acid under the same conditions is stable for 2 months, a $1 \%$ solution of $\mathrm{Ni}\left(\mathrm{NO}_{3}\right)_{2}$ is for 4 months.

Thus, as a result of the study, the technique for quantitative determining of $\mathrm{Cd}, \mathrm{Pb}$ and As using ETAAS in substances from a plant raw materials was developed and suggested for implementation to new edition of Ph. Rus.

\section{Conclusions}

The technique for the quantitative determination of cadmium, lead and arsenic using the inexpensive (compared to ICP-MS) ETAAS method in solutions obtained by acid decomposition of medicinal plant raw materials at low temperatures under microwave heating has been developed and made it possible to significantly speed up and automate the sample preparation procedure. Low decomposition temperatures (less than $200^{\circ} \mathrm{C}$ ) avoid the danger of uncontrolled pressure build-up in the vessels and, accordingly, their explosion. The use of inexpensive commercially available reagents solutions ( $1 \%$ ascorbic acid solution for lead and $1 \% \mathrm{Ni}\left(\mathrm{NO}_{3}\right)_{2}$ solution for arsenic) as modifiers made it possible to abandon extremely expensive palladium modifiers, as well as modifiers recommended by Eur. Ph., since the last are not always available in the required purity for ETAAS. The prospects of the developed technique for the quality control of natural substances for the content of the most toxic inorganic eco-toxicants - cadmium, lead, arsenic are shown. The proposed technique can also be recommended for controlling the accumulation of cadmium, lead and arsenic in plant organisms.

\section{Acknowledgement}

This paper has been supported by the RUDN University Strategic Academic Leadership Program.

\section{Conflict of interest}

The authors declare no conflict of interest. 


\section{References}

1. Agatemor C, Beauchemin D, Matrix effects in inductively coupled plasma mass spectrometry: A review. Anal Chim Acta, 2011; 706(1): 66-83.

2. Anal JMH, Chase P, Trace elements analysis in some medicinal plants using graphite furnace-atomic absorption spectroscopy. Environ Eng Res., 2016; 21(3): 247-255.

3. British Pharmacopoeia. $7^{\text {th }}$ ed.; Crown: London, 2009.

4. Bulska E, Ruszczyńska A, Analytical techniques for trace element determination. Physic Sci Rev., 2017; 2(5): 20178002.

5. da Silva DB, Junior MMS, Silva LOB, Portugal LA, Matos GD, Ferreira SLC, Determination of cadmium in rice by electrothermal atomic absorption spectrometry using aluminum as permanent modifier. Anal Methods, 2011; 3: 2495-500.

6. European Pharmacopoeia. $8^{\text {th }}$ ed.; European Directorate for the Quality of Medicines \& HealthCare: Strasbourg, 2014.

7. Gravel IV, Regional problems of ecological assessment of medicinal raw materials and phytopreparations on the example of the Altai territory. Ph. D. (Pharm.). Moscow, 2005, (available in Russian).

8. Jackwerth E, Gomiscek S, General aspects of trace analytical methods-VI. Acid pressure decomposition in trace element analysis. Pure Appl., 1984; 56: 480-489.

9. Junior MM, Silva LO, Leao DJ, Ferreira SL, Analytical strategies for determination of cadmium in Brazilian vinegar samples using ET AAS. Food Chem., 2014; 160: 209-213.

10. Kingston HM, Jassie LB, Introduction to microwave sample preparation. Theory and practice; Washington DS: ACS Professional reference book, 1988.

11. Kiseleva MS, Tyutyunnik OA, Nikulin AV, Kubrakova IV, Microwave sample preparation of natural objects using new technical solutions. Zavodskaya laboratoriya. Diagnostika materialov, 2014; 80: 7-11, (available in Russian).

12. Leykin AY, Yakimovich PV, Systems for the suppression of spectral interferences for inductively coupled plasma mass-spectrometry. J Analyt Chem., 2012; 67: 677686, (available in Russian).

13. Marinescu E, Elisei AM, Aprotosoaie AC, Cioancă O, Trifan A, Miron A, Robu S, Ifrim C, Hăncianu M, Assessment of heavy metals content in some medicinal plants and spices commonly used in Romania. Farmacia, 2020; 68(6): 1099-1105.

14. Nelms SM, Inductively coupled plasma mass spectrometry handbook; CRC Press: Boca Ration, 2005.

15. Niamat R, Khan MA, Khan KY, Ahmad M, Ali B, Mustafa M, Ahmad H, Element content of some ethnomedicinal Ziziphus Linn. species using atomic absorption spectroscopy technique. J Appl Pharm Sci., 2012; 2(3): 96-100.

16. Nikonov GK, Manuilov BM, Fundamentals of modern herbal medicine; Medicine, Moscow, 2005, (available in Russian).

17. Pohl P, Dzimitrowicz, A, Jedryczko D, SzymczychaMadeja A, Welna M, Jamroz P, The determination of elements in herbal teas and medicinal plant formulations and their tisanes. J Pharm Biomed Anal., 2016; 130: 326-335.

18. Pupishev AA, Atomic absorption spectral analysis; Tekhnosphera, Moscow, 2009, (available in Russian).

19. Sardans J, Montes F, Peñuelas J, Determination of $\mathrm{As}, \mathrm{Cd}, \mathrm{Cu}, \mathrm{Hg}$ and $\mathrm{Pb}$ in biological samples by modern electrothermal atomic absorption spectrometry. Spectrochimica Acta. Part. B, 2010; 65(2): 97-112.

20. Sedikh EM, Atomization of silver, lead, cobalt, nickel and tellurium compounds in the process of electrothermal atomic absorption analysis of samples of complex composition. Ph D. (Chem.). Moscow, 1980, (available in Russian).

21. State Pharmacopoeia of the Russian Federation. XIV ${ }^{\text {th }}$ ed. Ministry of Healthcare of Russian Federation: Moscow, 2018, (available in Russian).

22. The International Pharmacopoeia [electronic resource]. $9^{\text {th }}$ ed.; World Health Organization: Geneva, 2019.

23. The Japanese Pharmacopoeia [electronic resource]. XVII $^{\text {th }}$ ed.; English version. The Ministry of health, labour and welfare, 2016.

24. The United States pharmacopeia. $36^{\text {th }}$ rev. NF $31^{\text {st }}$ ed. The United States Pharmacopeial Convention: Rockvill, 2013.

25. Thongsaw A, Chuachuad Chaiyasith W, Sanannmuang R, Ross GM, Ampiach-Bonney RJ, Determination of cadmium in herbs by SFODME with ETAAS detection. Food Chem., 2017; 219: 453-458.

26. Tsalev DL, Slaveykova VO, Lampugnani L, Ulivo AD, Georgieva R, Permanent modification in electrothermal atomic absorption spectrometry - advances, anticipation and reality. Spectrochim Acta Part B, 2000; 55(5): 473-490.

27. Tyutyunnik OA, Getsina ML, Toropchenova ES, Kubrakova IV, Microwave preparation of natural samples to the determination of mercury and other toxic elements by atomic absorption spectrometry. $J$ Anal Chem., 2013; 68: 377-385, (available in Russian).

28. Welz B, Schlemmer G, Mudakavi JR, Palladium nitrate-magnesium nitrate modifier for electrothermal atomic absorption spectrometry. Part 5. Performance for the determination of 21 elements. JAAS, 1992; 7: 1257-1271. 